\title{
Chemical and Biological Evaluation of Nutritional Characteristics of Egyptian Pecan
}

\author{
Laila A. Shekib, Nahid M. El-Shimy and Nesrin A. El-Shehy ${ }^{*} 1$
}

\begin{abstract}
Two different cultivars of pecan, Carya illinoinensis, grown in Egypt, namely: Desirable and Moneymaker were analyzed for their amino acids composition, chemical score, protein efficiency ratio (PER) and net protein ratio (NPR) as parameters for their protein quality. Moreover, total cholesterol (TC), cholesterol fractions and serum triglycerides of experimental rats fed on pecan were determined.

The concentration of arginine in pecan protein was found in high amount (166.94 and $147.20 \mathrm{mg} / \mathrm{g}$ protein for Desirable and Moneymaker, respectively) which offers health benefits. Lysine was the first limiting amino acid in both cultivars and the chemical score was 0.75 for Desirable and 0.66 for Moneymaker pecan cultivars. The protein quality of Desirable cultivar was higher than that of Moneymaker, meanwhile, they both had good protein quality where their Adj-PER and NPR were 2.30, 2.25 and 3.27, 3.25, for Desirable and Moneymaker cultivars, respectively, compared to $\mathbf{2 . 5 0}$ and $\mathbf{3 . 4 3}$ for casein diet as a reference protein. The blood serum analysis of the rat groups fed on pecan diet had lower levels of LDL-C, V.LDL-C and triglycerides, but had higher level of HDL-C than those fed on casein diet.
\end{abstract}

Our results show that the protein of pecan kernels (plant protein) is in good quality, especially for Desirable cultivar, and their fat may improve human serum lipid profile by lowering LDL-C and V.LDL-C and increasing HDL-C.

Keywords: Amino acids, Cholesterol fractions, Net protein ratio (NPR), Pecan, Protein efficiency ratio (PER).

\section{INTRODUCTION}

Pecan (Carya illinoinensis) belongs to the family Juglandaceae, which also includes other tree nuts such as walnuts (McHatton, 1957 and Rosengarten, 1984). It is successfully cultivated in subtropical zones. Pecan trees were known in Egypt in the last years of the $20^{\text {th }}$ century, where it has been successfully grown in scattered areas.

Nuts and seeds have a wide range of uses, they tend to be either used as snack items or added as minor ingredient to savory and sweet dishes, moreover, they have wider applications in vegetarian diets as important sources of protein, unsaturated fatty acids, tocopherols and other nutrients (Gray, 2005).

\footnotetext{
${ }^{1}$ Food Science and Technology Department, Faculty of Agriculture, University of Alexandria, Alexandria, Egypt

*Corresponding to: Nesrin A. El-Shehy

E-mail address: doc.nesrin_elshehy@hotmail.com

Received May25, 2011, Accepted June 30, 2011
}

Nuts may be source of health promoting compounds that elicit cardioprotective effects. In particular, nuts include plant protein, polyunsaturated fatty acids, dietary fibers, plant sterols phytochemicals and micronutrients like; tocopherols, copper, magnesium and folic acid (Kris-Etherton et al., 2001 and Nijjar, et al. 2010). These components likely combine to reduce LDL-C beyond the effects of those predicted by equations based solely on fatty acid profiles (Van Horn, 2008). At present, nuts are classified as part of the USDA Food Guide pyramids Meat/Meat Alternate Group (Dreher et al., 1996). In July 2003 the US Food and Drug Administration (FDA) approved a qualified health claim stating that consumption of $42 \mathrm{~g}$ per day of most tree nuts may reduce the risk of heart disease. Amino acid composition analyses indicated that lysine in pecan, brazil nut, cashew and walnut; sulfur amino acids in almond to be the first limiting amino acid as compared to human amino acids requirements (Venkatachalam and Sathe, 2006). There are little information about the nutritive value of pecan protein and its effect on human health. Therefore, this study was conducted to study the nutritive value of two Egyptian pecan cultivars by determining their amino acids composition, PER and NPR. Moreover, blood serum cholesterol and triglycerides were determined using animal feeding experiments.

\section{MATERIALS AND METHODS}

\subsection{Materials}

Two cultivars of in shell pecan fruits namely: Desirable and Moneymaker were brought from Agriculture Ministry of Egypt. The fruits were shelled and the kernels were packed in polyethylene bags and stored at $\left(-16--18^{\circ} \mathrm{C}\right)$ until required. The samples were prepared for chemical analysis by grinding the pecan kernels to pass through a 40 mesh sieve.

\subsection{Analytical methods}

Moisture, crude ether extract and crude protein were determined as described by the AOAC (2003). Amino acids composition was determined by the method of Duranti and Cerletti (1979) using Beckman amino acid analyzer Model $19 \mathrm{Cl}$. For the determination of Tryptophan the samples were subjected to alkaline 
Table 2. Ingredients for blood serum profiles and triglycerides determination

\begin{tabular}{lc}
\hline \multicolumn{1}{c}{ Reagent constituents } & Concentration \\
\hline \multicolumn{2}{l}{ Blood serum cholesterol determination } \\
\hline 4-Aminoantipyrine & $0.26 \mathrm{mmol} / \mathrm{L}$ \\
\hline Phenol & $8.06 \mathrm{mmol} / \mathrm{L}$ \\
\hline $\begin{array}{l}\text { Cholesterol esterase (Candida } \\
\text { Cylindracea) }\end{array}$ & $211 \mathrm{IU} / \mathrm{L}$ \\
\hline $\begin{array}{l}\text { Cholesterol oxidase } \\
\text { (Brevibacterium Maris) }\end{array}$ & $216 \mathrm{IU} / \mathrm{L}$ \\
\hline Horseradish peroxidase (HPO) & $6667 \mathrm{IU} / \mathrm{L}$ \\
\hline $\begin{array}{l}\text { Blood serum high density lipoprotein }(\text { HDL }) \\
\text { determination }\end{array}$ & $1250 \mathrm{IU} / \mathrm{L}$ \\
\hline $\begin{array}{l}\text { Cholesterol esterase (Candida } \\
\text { Cylindracea) }\end{array}$ & $1600 \mathrm{IU} / \mathrm{L}$ \\
\hline $\begin{array}{l}\text { Cholesterol oxidase } \\
\text { Brevibacterium Maris) }\end{array}$ & $5000 \mathrm{IU} / \mathrm{L}$ \\
\hline Horseradish peroxidase (HPO) & $0.1 \%$ \\
\hline Polyanion & $1.0 \%$ \\
\hline Detergent & $93 \mathrm{U} / \mathrm{L}$ \\
\hline Blood serum triglycerides determination \\
\hline Lipase & $2.52 \mathrm{mmol} / \mathrm{L}$ \\
\hline Adenosine triphosphate (ATP) & $4.0 \mathrm{KIU} / \mathrm{L}$ \\
\hline Glycerol Kinase (GK) & $1.1 \mathrm{KIU} / \mathrm{L}$ \\
\hline Glycerophosphate oxidase (GPO) & $0.71 \mathrm{mmol} / \mathrm{L}$ \\
\hline 4-Aminoantipyrine & $1.54 \mathrm{mmol} / \mathrm{L}$ \\
\hline $\begin{array}{l}\text { 3,5 Dichloro-2- } \\
\text { Hydroxybenzenesulfonic acid } \\
\text { (DHBS) }\end{array}$ & $9.0 \mathrm{KIU} / \mathrm{L}$ \\
\hline Horseradish peroxidase (HPO) & \\
\hline
\end{tabular}

\section{RESULTS AND DISCUSSION}

\subsection{Amino acids composition}

Table (3) shows the amino acids composition as (mg/g protein) of pecan cultivars compared to FAO/WHO pattern for children. It is obvious that the major amino acids of pecan are glutamic acid followed by arginine for both cultivars Desirable and Moneymaker. The relatively high content of arginine in nuts may help in raising levels of endogenous nitric oxide, which promotes normal endothelial function and has effects to inhibit platelet aggregation, monocyte adherence, chemotoxis, and vascular smooth muscle proliferation (Loscalzo, 1995; Fraser, 1999 and De Lorgeril and Salen, 2004).

From the essential amino acids results (Table; 3), it can be seen that Desirable cultivar had significantly high content in most of the essential amino acids, and the total essential amino acids of Desirable cultivar are higher than that of Moneymaker cultivar. At the same time, both cultivars provided all the essential amino acids at higher concentration compared to the pattern of FAO/WHO for 2-5 years old children, except for lysine and threonine.
The essential amino acid scores of raw pecan kernels cultivars are presented in Table (4). The chemical score for Desirable cultivar (0.75) was higher than that of Moneymaker one (0.66). Lysine was the first limiting amino acid for both cultivars and threonine was the second one in Moneymaker only.

Venkatachalam (2004) found that lysine was the first limiting essential amino acids in the defatted flour of pecan. Threonine and tryptophan were the second and the third ones.

Moreover, Venkatachalam and Sathe (2006) reported that lysine in pecan, brazil nut, cashew and walnut, sulfur amino acids in almond, to be the first limiting amino acid as compared to human (2-5 years old) amino acids requirements.

1.7. Average weight gain, protein efficiency ratio (PER) and net protein ratio (NPR) of rats fed on casein and pecan diets

Average weight gain, protein efficiency ratio (PER) and net protein ratio (NPR) of rats fed on casein and pecan diets are given in Table (5).

The results indicate that the average weight gain for rats, which were fed on the casein and pecan cultivars diets were as follows in descending order: $35.30 \mathrm{~g}$ for casein, $32.11 \mathrm{~g}$ for Desirable cultivar and $31.25 \mathrm{~g}$ for Moneymaker cultivar. Moreover, when adjusted PER was calculated for the forementioned diets, it was found that, Desirable and Moneymaker pecan had slightly, but significantly, lower values, 2.30 and 2.25 , respectively, than that of casein (2.50) as a reference protein. Meanwhile, net protein ratio (NPR) for pecan diets were 3.27 and 3.25 for Desirable and Moneymaker cultivars, respectively, which are not far from that of casein diet (3.43). The high growth of the rats which were fed on pecan diets can be confirmed by the results of Table (3), which showed that pecan protein had high amounts of essential amino acids. Estevez et al. (1995) studied the PER and NPR of walnut snack type bars and reported that walnut protein has good quality as compared to casein. So, it can be concluded that pecan protein, as plant protein, is considered a high quality protein, which gives it an advantage as a protein source for vegetarians and children.

\subsection{Blood serum cholesterol picture and triglycerides}

Table (6) shows the data of total cholesterol (TC), high density lipoprotein cholesterol (HDL-C), low density lipoprotein cholesterol (LDL-C), very low density lipoprotein cholesterol (V.LDL-C), LDL: HDL and triglycerides (TG) in the serum of rats fed on casein and raw pecan Desirable and Moneymaker cultivars, for 4 weeks. 
Table 3. Amino acids composition of raw pecan cultivars proteins

\begin{tabular}{|c|c|c|c|c|}
\hline \multirow{2}{*}{$\begin{array}{l}\text { Amino acids composition } \\
\text { (mg /g protein) }\end{array}$} & \multicolumn{2}{|c|}{ Cultivars } & \multirow{2}{*}{ L.S.D } & \multirow{2}{*}{$\begin{array}{c}\text { FAO/WHO pattern } \\
(\mathbf{1 9 8 5}) * *\end{array}$} \\
\hline & Desirable & Moneymaker & & \\
\hline Crude protein & $9.15^{a^{n}}$ & $\mathbf{8 . 0 8}^{\mathbf{b}}$ & 0.27 & \\
\hline \multicolumn{5}{|l|}{$\begin{array}{l}\text { Essential Amino acids } \\
\text { (E.A.A) }\end{array}$} \\
\hline Isoleucine & $47.05^{\mathrm{a}}$ & $41.55^{\mathrm{b}}$ & 0.41 & 28.00 \\
\hline Leucine & $76.30^{\mathrm{a}}$ & $67.38^{\mathrm{b}}$ & 0.42 & 66.00 \\
\hline Lysine & $43.42^{\mathrm{a}}$ & $38.34^{\mathrm{b}}$ & 0.49 & 58.00 \\
\hline Threonine & $37.03^{\mathrm{a}}$ & $32.70^{\mathrm{b}}$ & 0.50 & 34.00 \\
\hline Valine & $55.57^{\mathrm{a}}$ & $49.07^{\mathrm{b}}$ & 0.44 & 35.00 \\
\hline Tryptophan & $19.98^{\mathrm{a}}$ & $17.64^{\mathrm{b}}$ & 0.50 & 11.00 \\
\hline Methionine & $23.90^{\mathrm{a}}$ & $21.10^{\mathrm{b}}$ & 0.41 & \\
\hline Cystine & $16.71^{\mathrm{a}}$ & $14.75^{\mathrm{b}}$ & 0.43 & \\
\hline Methionine + Cystine & $40.61^{a}$ & $35.85^{\mathrm{b}}$ & 0.48 & 25.00 \\
\hline Phenylalanine & $63.19^{\mathrm{a}}$ & $55.80^{\mathrm{b}}$ & 0.53 & \\
\hline Tyrosine & $43.79^{\mathrm{a}}$ & $38.67^{\mathrm{D}}$ & 0.66 & \\
\hline Phenylalanine + Tyrosine & $106.98^{\mathrm{a}}$ & $94.47^{\mathrm{b}}$ & 0.67 & 63.00 \\
\hline Histidine & $32.24^{\mathrm{a}}$ & $28.47^{\mathrm{b}}$ & 0.51 & 19.00 \\
\hline Total E.A.A & $459.18^{\mathrm{a}}$ & $405.47^{0}$ & 0.36 & 339.00 \\
\hline \multicolumn{5}{|l|}{$\begin{array}{l}\text { Limiting Essential Amino } \\
\text { acids (LEAA) }\end{array}$} \\
\hline First & Lysine & Lysine & & \\
\hline Second & - & Threonine & & \\
\hline \multicolumn{5}{|l|}{$\begin{array}{l}\text { Non Essential Amino } \\
\text { acids (N.E.A.A) }\end{array}$} \\
\hline Arginine & $166.94^{\mathrm{a}}$ & $147.42^{\mathrm{b}}$ & 0.36 & \\
\hline Aspartic acid & $102.67^{\mathrm{a}}$ & $90.67^{\mathrm{b}}$ & 0.40 & \\
\hline Glutamic acid & $217.87^{\mathrm{a}}$ & $192.39^{\mathrm{b}}$ & 0.66 & \\
\hline Glycine & $52.60^{\mathrm{a}}$ & $46.45^{\mathrm{D}}$ & 0.53 & \\
\hline Proline & $50.25^{\mathrm{a}}$ & $44.37^{\mathrm{b}}$ & 0.66 & \\
\hline Serine & $51.11^{\mathrm{a}}$ & $45.14^{\mathrm{b}}$ & 0.52 & \\
\hline Alanine & $47.49^{\mathrm{a}}$ & $41.93^{\mathrm{b}}$ & 0.53 & \\
\hline Total N.E.A.A & $688.93^{\mathrm{a}}$ & $608.37^{b}$ & 0.57 & \\
\hline
\end{tabular}

\section{Table 4. Essential amino acid scores of pecan kernel cultivars}

\begin{tabular}{|c|c|c|c|c|c|}
\hline \multirow{2}{*}{$\begin{array}{l}\text { Essential amino acids } \\
\text { composition } \\
\text { (mg/g protein) }\end{array}$} & \multicolumn{2}{|c|}{ Cultivars } & \multirow{2}{*}{$\begin{array}{c}\text { FAO/WHO } \\
\text { pattern } \\
(1985)^{* *}\end{array}$} & \multicolumn{2}{|c|}{ Chemical score $^{1}$} \\
\hline & Desirable & Moneymaker & & Desirable & Moneymaker \\
\hline Isoleucine & $47.05^{\mathrm{a}^{*}}$ & $41.55^{\mathrm{b}}$ & 28.00 & 1.68 & 1.48 \\
\hline Leucine & $76.30^{\mathrm{a}}$ & $67.38^{\mathrm{b}}$ & 66.00 & 1.16 & 1.02 \\
\hline Lysine & $43.42^{\mathrm{a}}$ & $38.34^{\mathrm{b}}$ & 58.00 & $0.75 * * *$ & $0.66^{* * *}$ \\
\hline Threonine & $37.03^{\mathrm{a}}$ & $32.70^{\mathrm{b}}$ & 34.00 & 1.09 & 0.96 \\
\hline Valine & $55.57^{\mathrm{a}}$ & $49.07^{\mathrm{b}}$ & 35.00 & 1.59 & 1.40 \\
\hline Tryptophan & $19.98^{\mathrm{a}}$ & $17.64^{\mathrm{b}}$ & 11.00 & 1.82 & 1.60 \\
\hline Methionine + Cystine & $40.61^{\mathrm{a}}$ & $35.85^{\mathrm{b}}$ & 25.00 & 1.62 & 1.43 \\
\hline Phenylalanine + Tyrosine & $106.98^{\mathrm{a}}$ & $94.47^{\mathrm{b}}$ & 63.00 & 1.70 & 1.50 \\
\hline Histidine & $32.24^{\mathrm{a}}$ & $28.47^{\mathrm{b}}$ & 19.00 & 1.70 & 1.50 \\
\hline Total E.A.A & $459.18^{\mathrm{a}}$ & $405.47^{\mathrm{b}}$ & 339.00 & & \\
\hline
\end{tabular}

* Means between columns sharing the same letters are not significantly different, using the revised L.S.D test at 0.05 level.

** From FAO/WHO pattern (1985) for weaned (2-5 years) children.

*** The first limiting amino acids.

1- Essential amino acid scores calculated by dividing the essential amino acid amount (E.A.A) mg/g protein by the same value of E.A.A of the FAO/WHO pattern. 
Table 5. Weight gain, Food intake, and Protein intake of rats fed on casein and pecan diets

\begin{tabular}{|c|c|c|c|c|c|c|}
\hline Food Group & $\begin{array}{c}\text { Average } \\
\text { Weight gain (g) } \\
\text { M } \pm \mathrm{SD}^{*}\end{array}$ & $\begin{array}{c}\text { Average } \\
\text { Food intake (g) } \\
\text { M } \pm \text { SD }\end{array}$ & $\begin{array}{c}\text { Average } \\
\text { Protein } \\
\text { intake (g) } \\
\text { M } \pm \text { SD } \\
\end{array}$ & $\begin{array}{c}\text { PER }^{1} \\
\mathbf{M} \pm \mathrm{SD}^{*}\end{array}$ & $\begin{array}{c}\text { Adj-PER }^{2} \\
\mathrm{M} \pm \mathrm{SD}\end{array}$ & $\begin{array}{c}\mathbf{N P R}^{3} \\
\mathrm{M} \pm \mathrm{SD}\end{array}$ \\
\hline $\begin{array}{c}\begin{array}{c}\text { Casein } \\
\text { (Reference) }\end{array} \\
\end{array}$ & $35.30^{\mathrm{a}^{* *}} \pm 2.88$ & $162.50^{\mathrm{a}^{* *}} \pm 7.81$ & $16.10^{\mathrm{a}} \pm 0.76$ & $2.20^{\mathrm{a}^{* *}} \pm 0.13$ & $2.50^{\mathrm{a}} \pm 0.00$ & $3.43^{\mathrm{a}} \pm 0.21$ \\
\hline हี Desirable & $32.11^{\mathrm{b}} \pm 2.87$ & $160.79^{\mathrm{b}} \pm 7.80$ & $15.92^{\mathrm{b}} \pm 0.75$ & $2.02^{\mathrm{b}} \pm 0.12$ & $2.30^{\mathrm{b}} \pm 0.10$ & $3.27^{\mathrm{b}} \pm 0.21$ \\
\hline ¿ี Moneymaker & $31.25^{\mathrm{c}} \pm 2.87$ & $159.53^{\mathrm{c}} \pm 7.82$ & $15.79^{\mathrm{c}} \pm 0.74$ & $1.98^{\mathrm{c}} \pm 0.12$ & $2.25^{\mathrm{c}} \pm 0.10$ & $3.25^{\mathrm{c}} \pm 0.21$ \\
\hline L.S.D & 0.266 & 0.640 & 0.124 & 0.056 & 0.018 & 0.017 \\
\hline \multicolumn{7}{|c|}{$\begin{array}{l}* \mathrm{M} \pm \mathrm{SD}=\text { Mean } \pm \text { Standard Deviation. } \\
* * \text { Means in the same column sharing the sa }\end{array}$} \\
\hline \multicolumn{7}{|c|}{1 - PFP - Weĩght gaîn } \\
\hline \multicolumn{7}{|c|}{ P \oteîn întake } \\
\hline \multicolumn{7}{|c|}{ PER $\times 2 x \frac{5}{-}$} \\
\hline \multicolumn{7}{|c|}{ 2- Adj-PER $=\quad$ PER for referenc $\square$ proteĩn (caseĩn) } \\
\hline \multicolumn{7}{|c|}{ Weĩght gaîn + weĩght loss *** } \\
\hline $3-\mathrm{NPR}=$ & tein intake & & loss from the & protein group. & & \\
\hline
\end{tabular}

Table 6. Blood serum total cholesterol (TC), cholesterol fractions and triglycerides (TG) (mmol/L) of rats fed on casein and pecan diets

\begin{tabular}{|c|c|c|c|c|c|c|}
\hline Food Group & $\begin{array}{c}\text { Total } \\
\text { Cholesterol } \\
\text { (TC) } \mathrm{M} \pm \mathrm{SD}^{*}\end{array}$ & $\begin{array}{c}\text { HDL-C } \\
\mathrm{M} \pm \mathrm{SD}\end{array}$ & $\begin{array}{c}\text { LDL-C } \\
\mathrm{M} \pm \mathrm{SD}\end{array}$ & $\begin{array}{c}\text { V.LDL-C } \\
\mathrm{M} \pm \mathrm{SD}\end{array}$ & $\begin{array}{c}\text { LDL:HDL } \\
\text { Ratio } \\
\text { M } \pm \text { SD }\end{array}$ & $\begin{array}{c}\text { Triglycerides } \\
\text { (TG) } \\
\text { M } \pm \text { SD }\end{array}$ \\
\hline Casein (I & $4.32^{\mathrm{a}^{* * *}} \pm 0.26$ & $0.67^{\mathrm{b}} \pm 0.34$ & $3.11^{\mathrm{a}} \pm 0.19$ & $0.43^{\mathrm{a}} \pm 0.21$ & $4.64: 1^{\mathrm{a}} \pm 0.20$ & \\
\hline 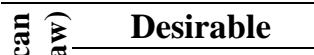 & $2.71^{\mathrm{b}} \pm 0.33$ & $0.83^{\mathrm{a}} \pm 0.44$ & $1.66^{\mathrm{b}} \pm 0.23$ & $0.19^{\mathrm{b}} \pm 0.25$ & $2.00: 1^{\mathrm{b}} \pm 0.11$ & $0.95^{\mathrm{c}} \pm 0.50$ \\
\hline Moneymaker & $2.76^{\mathrm{b}} \pm 0.20$ & $0.83^{\mathrm{a}} \pm 0.33$ & $1.77^{\mathrm{b}} \pm 0.21$ & $0.21^{\mathrm{b}} \pm 0.26$ & $2.13: 1^{\mathrm{b}} \pm 0.13$ & $1.05^{\mathrm{b}} \pm 0.43$ \\
\hline L.S.D & 0.079 & 0.018 & 0.111 & 0.056 & 0.785 & 0.096 \\
\hline
\end{tabular}

$* \mathrm{M} \pm \mathrm{SD}=$ Mean \pm Standard Deviation.

**Means in the same column sharing the same letters are not significantly different, using the revised L.S.D test at 0.05 level.

1-HDL-C = High Density Lipoprotein Cholesterol. $\quad 2-$ LDL-C = Low Density Lipoprotein Cholesterol.

3- V.LDL-C = Very Low Density Lipoprotein Cholesterol.

The results indicated that there was a significant reduction in the level of the total cholesterol (TC), low density lipoprotein cholesterol (LDL-C), very low density lipoprotein cholesterol (V.LDL-C), LDL: HDL and triglycerides (TG) in the blood serum of the rats fed on the Desirable and Moneymaker cultivars of raw pecan diets compared to those fed on casein diet.

Total cholesterol (TC) was $4.32 \mathrm{mmol} / \mathrm{L}$ for the rats fed on casein diet and was 2.71 and $2.76 \mathrm{mmol} / \mathrm{L}$ for the rats which were fed on raw pecan (Desirable and Moneymaker) diets, respectively. On the other hand, high density lipoprotein cholesterol (HDL-C) significantly increased from $0.67 \mathrm{mmol} / \mathrm{L}$ for the rats fed on casein diet to 0.83 and $0.83 \mathrm{mmol} / \mathrm{L}$ for those fed on raw pecan cultivars diets, respectively.

Meanwhile, low density lipoprotein cholesterol (LDL-C) and very low density lipoprotein cholesterol (V.LDL-C) were 3.11 and $0.43 \mathrm{mmol} / \mathrm{L}$ in the blood serum of the rats fed on casein diet, respectively, while they were $1.66,0.19$ and $1.77,0.21 \mathrm{mmol} / \mathrm{L}$, for the rats fed on raw Desirable and Moneymaker diets, respectively.

Moerover, Nijjar et al. reported, in their review (2010), that nut kernels particular walnuts may improve human serum lipid profile by lowering low density lipoprotein cholesterol (LDL-C) and very low density lipoprotein cholesterol (V.LDL-C), because they are composed largely of polyunsaturated fatty acids, especially alpha-linolenic acid and linolenic acid. In addition to lowering serum cholesterol, pecan-enriched diets also increased high density lipoprotein cholesterol (HDL-C)

Nagaraju and Belur (2008) reported that rats which were fed on blended oils containing peanuts oil reduced the susceptibility of low density lipoprotein (LDL-C) cholesterol to oxidation, enhanced hepatic antioxidant enzymes and decreased lipid peroxidation in liver. Oxidized LDL-C plays an important role in 
atherosclerosis. Furthermore, Aksoy et al. (2007) studied the effects of pistachio nuts intake on rats serum lipids oxidation. They reported that consumption of pistachio nuts as $20 \%$ of daily caloric intake increased the high density lipoprotein (HDL-C) cholesterol and the total cholesterol (TC) to HDL ratio, compared to those not taking pistachio nuts.

Moreover, when the ratio between LDL and HDL was calculated (Table; 6), it was found that LDL: HDL was 4.64:1 for casein and significantly decreased to 2.00:1 and 2.13:1 for Desirable and Moneymaker pecan cultivars diets, respectively.

Kinosian et al. (1995) showed that the changes in TC/HDL and LDL/HDL ratios were better predictors of coronary artery disease than the changes in LDL alone. Epidemiologic studies and studies in animals suggest that raising the levels of HDL cholesterol may retard the development of atherosclerosis. In humans, each increase in baseline HDL cholesterol by $1 \mathrm{mg} / \mathrm{dl}(0.03$ $\mathrm{mmol} / \mathrm{L}$ ) is associated with $6 \%$ decrease in the risk of death from coronary disease or myocardial infection (Gordon et al., 1986).

Triglycerides (TG) values were also presented in Table (6). It is clear that feeding the rats on pecan diets reduced the triglycerides (TG) content in their blood serum compared to those fed on casein diet. It was significantly reduced from $2.15 \mathrm{mmol} / \mathrm{L}$ for casein diet to 0.95 and 1.05 for raw pecan (Desirable and Moneymaker cultivars) diets, respectively. These results are in good agreement with Rajaram et al. (2001) who reported that pecan enriched diets lowered triacylglycerol (TAG) concentrations, leading to favourably altering the lipid profile.

\section{CONCLUSION}

These results show that the protein of pecan kernels were of good quality, especially for Desirable cultivars. Also pecan lipid has a good effect on serum lipid profile by lowering LDL-C and V.LDL-C and increasing HDLC.

\section{RE FERENCES}

Aksoy, N., Aksoy, M.; Bagci, C., Gergerlioglu, H. S., Celik, H., Herken, E., Yaman, A., Tarakcioglu, M., Soyding, S., Sari, I., and Davutoglu, V. (2007). Pistachio intake increases high density lipoprotein levels and inhibits low density lipoprotein oxidation in rats. Tohoku J. Exp. Med. 212: 43-48.

Association of Official Analytical Chemists (AOAC). (2003). Official methods of analytical. Helrich, K. ed. $17^{\text {th }}$ ed. Virginia, USA.

De Lorgeril, M., and Salen, P. (2004). Alpha-linolenic acid and coronary heart disease. Nutr. Metab. Cardiovasc. Dis. 14: 162-169.
Dreher, M. L., Maher, C. V., and Kearney, P. (1996). The traditional and emerging role of nuts in healthful diets. Nutr. Rev. 54: 241-245.

Duranti, M., and Cerletti, P. (1979). Amino acid composition of seed proteins. J. Agric. Food Chem. 27: 977-978.

El-Shimy, N. M., Shekib, L. A., and El-Shehy, N. A. (2011). Chemical properties and lipid profile of Egyptian pecan. Assiut J. Agric. Sci. (in press).

Estevez, A. M., Escobar, B., Vasquez, M., Castillo, E., Araya, E., and Zacarias, I. (1995). Cereal and nut bars, nutritional quality and storage stability. Plant Foods Human Nutr. 47: 309-317.

FAO/WHO/UNU Expert Consultation. (1985). Energy and Protein Requirements. Technical Report Series 724. World Health Organization. Geneva.

Fraser, G. E. (1999). Nut consumption, lipids and risk of a coronary event. Clin. Cardiol. 22(3):11-15.

Gordon, D. J., Knoke, J., Probstfield, J. L, Superko, R., and Tyroler, H. A. (1986). High density lipoprotein cholesterol and coronary heart disease in hypercholesterolemic men: the lipid research Clinics Coronary Primary Prevention Trial. Circulation. 74:1217-1225.

Gray, J. (2005). Nuts and seeds. Encyclopedia of Human Nutr. 381-388.

Kinosian, B., Glick, H., Preiss, L., and Puder, K. L. 1995. Cholesterol and coronary heart disease: Predicting risks in men by changes in levels and ratios. J. Inves. Med. 43: 443-450.

Kris-Etherton, P. M., Zhao, G., Binkoski, A. E., Coval, S. M., and Etherton, T. D. (2001). The effects of nuts on coronary heart disease risk. Nutr. Rev. 59(4): 103-111.

Loscalzo, J. (1995). Nitric oxide and vascular disease. N. Engl. J. Med. 333: 251-253.

McHatton, T. H. (1957). The history distribution and naming of pecan (Hicora pecan). Proceeding of the $50^{\text {th }}$ Southeastern Pecan Growers Association. 10-34.

Nagaraju, A., and Belur, L. R. (2008). Rats fed blended oils containing coconut oil with groundnut oil or olive oil showed as enhanced activity of hepatic antioxidant enzymes and a reduction in LDL oxidation. Food Chem. 108: 950-957.

Nijjar, P. S., Burke, F. M., Bloesch, A. and Rader, D. J. (2010). Role of dietary supplements in lowering lowdensity lipoprotein cholesterol: A review. J. Clinical Lipidology. 4, 248-258.

Rajaram, S., Burke, K., Connell, B., Myint, T., and Sabate, J. (2001). A monounsaturated fatty acid-rich pecan enriched diet favorably alters the serum lipid profile of healthy men and women. J. Nutr. 131: 2275-2279.

Rosengarten, F. R. (1984). The book of edible nuts. Walker and company, New York, USA.

Steel, R. G., and Torrie, J. H. (1980). Principles and procedures of statistics. $2^{\text {nd }}$ ed., McGrawe-Fill, New York, USA. 
SYNCHRON LX system chemistry information manual 962288. (2000). Beckman Coulter, Inc.

Van Horn, L., McCoin, M., and Kris-Etherton PM,. (2008). The evidence for dietary prevention and treatment of cardiovascular disease. J Am.Diet Assoc. 108:287-331.
Venkatachalam, M. (2004). Chemical composition of select Pecan [Carya illinoinensis (wangenh.) K. Koch] varieties and antigenic stability of pecan proteins. PhD Thesis. Nutr. Food and Exercise Sci. Dep. College of Human Sci. Florida State Univ. USA.

Venkatachalam, M., and Sathe, S. K. (2006). Chemical composition of selected edible nut seeds. J. Agric. Food Chem. 54(13): 4705-4714 


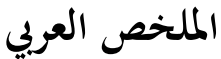

\section{التقييم الكيماوي والحيوي للخواص الغذائية للبيكان المصري}

$$
\text { ليلى عبد الهادي شكيب, ناهد مُحَّمَ الشيمي, نسرين عبد الهادي الشيحي }
$$

كما تبين من نتائج تغذية فئران التجارب أن القيمة الغذائية لبروتينات كل من صنفي البيكان تعتبر جيدة حيث كانت نسبة كل في سن

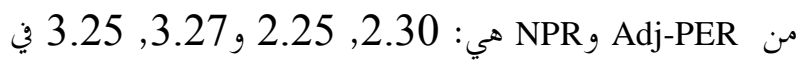

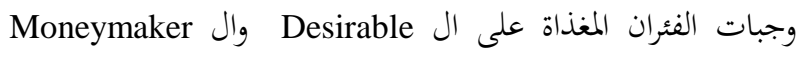
على التوالي مقارنة ب 2.50, 3.43 لبروتينات الكازين كبروتين مرجعي. أيضا أوضحت نتائج تحليل دم الفئران أن المجاميع التي تم تغذيتها على وجبات من البيكان قد حدث لما انخفاض في كل من الليبوبروتين

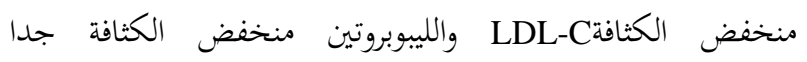
V.LDL-C بالقئران المغذاه على وجبة الكازين. وفي ضوء نتائج هذه الدراسة يتضح أن البيكان مصدر غذائي جيد ومفيد صحيا للمستهلك وأن وريك صنف ال Desirable أفضل من صنف Moneymaker من وجهة عيدة

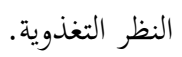

تم دراسة صنفين من البيكان (Carya illinoinensis) الذي يتم زراعته في مصر وهما Moneymaker, Desirable حيث تم التحليل الكمي للأحماض الأمينية ومنها تم حساب ال Chemical score كما تم حساب قيمة ال PER وال NPR كمقياسات لجودة البروتين باستخدام فئران التجارب. وأيضا تم تقدير الكولستيرول الكلي (TC) والليبوبروتين مرتفـع الكثافة HDL-C والليبوبروتين مسنخفض الكثافة

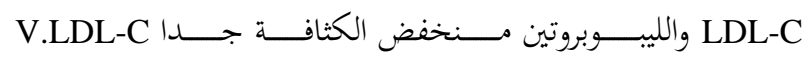
والجليسريدات الثلاثية (TG) في دم الفئران. وبينت النتائج أن الحامض الأميني الأرجنين يوجد بنسب مرتفعة

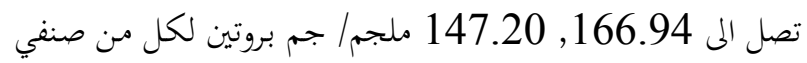
ال Desirable وال Moneymaker على التـوالي, وهـــا لـه فوائـد صحية كبيرة. من ناحية أخرى وجد أن الحامض الأميني ال Lysine

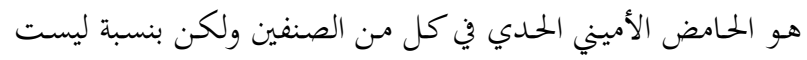

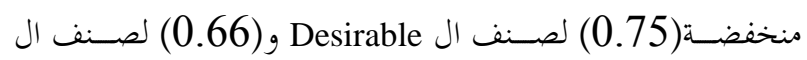

